\title{
Evaluation of Angiotensin-converting Enzyme 2 (ACE2) in COVID-19: A Systematic Review on All Types of Studies for Epidemiologic, Diagnostic, and Therapeutic Purposes
}

\author{
Houshang Nemati ${ }^{1}$, Mazaher Ramezani ${ }^{2}$, Farid Najafi ${ }^{3}$, Babak Sayad ${ }^{4}$, Mehri Nazeri ${ }^{1}$, Masoud Sadeghi ${ }^{5 *}$ \\ ${ }^{1}$ Fertility and Infertility Research Center, Health Technology Institute, Kermanshah University of Medical Sciences, Kermanshah, \\ Iran; ${ }^{2}$ Molecular Pathology Research Center, Imam Reza Hospital, Kermanshah University of Medical Sciences, Kermanshah, \\ Iran; ${ }^{3}$ Research Center for Environmental Determinants of Health, School of Public Health, Kermanshah, Iran; ${ }^{4}$ Department \\ of Infectious Disease, School of Medicine, Kermanshah University of Medical Sciences, Kermanshah, Iran; ${ }^{5}$ Medical Biology \\ Research Center, Kermanshah University of Medical Sciences, Kermanshah, Iran
}

\begin{abstract}
Severe acute respiratory syndrome coronavirus 2 (SARS-CoV-2) uses the angiotensin-converting enzyme 2 (ACE2) receptor of SARS-CoV for cell entry. We aimed to check the association between ACE2 and COVID-19 (coronavirus disease 2019) in a systematic review. Two databases (PubMed/Medline and Scopus) and bioRxiv were checked for retrieving all types of studies in relation to ACE2 and COVID-19 until March 18, 2020. Forty-one studies were entered to the systematic review. These studies included nineteen original, eight reviews, four letters to the editor, three research papers, one correspondence, one commentary, one mini review, two reports, one opinion, and one perspective. In summary, the results showed that the ACE2 receptor for COVID-19 is similar to that of SARS-CoV. However, its expression was different in various populations as well as in the two genders. ACE2 may be used as a therapeutic target. Patients who take ACE inhibitors may have benefit in severe disease outcomes. Finally, pangolins and snakes and turtles may act as the potential intermediate hosts transmitting disease to humans.
\end{abstract}

Edited by: Mirko Spirosk Citation: NematiH, Ramezani M, Najafi F, Sayad B, azeri M, Sadeghi M. Evaluation of Angiotensin-converting Enzyme 2 (ACE2) in COVID-19: A Systematic Review on All Types of Studies for Epidemiologic, Diagnostic, and 2020 May 20; 8(T1):84-91 https://doi.org/10.3889/oamjms.2020.4763 ords: Angiotensin-converting enzyme 2; Novel coronavirus 2019; COVID-19; Systematic review Correspondence: Masoud Sadeghi; Medical Biology Research Center, Kermanshah University of Medical
Sciences, Kermanshah 6714415185, Iran. Sciences, Kermanshah 6714415185, Iran Tel: (+98) 918-596-0644. E-mail: sadeghi_mbrc@yahoo.com
Received: 10-Apr-2020 Received: $10-A p r-2020$
Revised: $22-A p r-2020$ Accepted: $29-$ Apr-2020
Copyright: $\odot 2020$ Houshang Nemati Mehri Nazeri, Masoud Sadeghi Muding: Publication of this article was financially Funding: Publication of this article was financially
ed by the Scientific Foundation SPIROSKI, Skopje, Republic of Macedonis Competing Interest: The authors have declared that no
competing interest exists. Competing Interest: The authors have declared that no
competing interest exists. under the terms of the Creative Commons Attribution-
und NonCommercial 4.0 International License (CC BY-NC 4.0)

\section{Introduction}

COVID-19 or 2019 novel coronavirus epidemic caused by severe acute respiratory syndrome coronavirus 2 (SARS-CoV-2) was emerged in late December 2019 in Wuhan, China [1]. This disease has been rapidly expanded in the world with a short time [2] and it is named a COVID-19 pandemic. The COVID19 strains are genetically correlated to SARS-CoV and Middle-East respiratory syndrome coronavirus (MERSCoV) [3]. A hypothesis reported that angiotensin II type I receptor (AT1R) inhibitors might be helpful for COVID-19 patients who experience pneumonia and suggested the treatment of COVID-19 patients with AT1R blockers [4]. SARS-CoV-2 uses angiotensin-converting enzyme 2 (ACE2) as the receptor-binding domain for its spike (S) protein glycoproteins [4], [5], [6]. ACE2 is a negative regulator of the renin-angiotensin system and reduces angiotensin II [5]. Mutant S proteins are capable of detecting host receptors within species [6], [7]. Almost all the coronaviruses detect their host cells through $S$ proteins [8], [9]. Each $S$ protein consists of two subunits that the $S 1$ subunit contains a region called the receptor-binding domain (RBD) (targeting receptors in host cells) and the S2 subunit regulates membrane fusion between the virus and the host cells [10]. The single-cell transcriptomes showed that ACE2 and TMPRSS (transmembrane protease and serine) are highly expressed in AT2 (type II alveolar) cells of lung, esophageal upper epithelial cells, and absorptive enterocytes [11]. It was also reported an identity of more than $70 \%$ between the $S$ protein sequences of SARS-CoV and SARS-CoV-2 [12]. Different methods of nucleic acid testing, protein testing, and point-of-care testing are on the way along with imaging techniques for better diagnosis [13]. Herein, we aimed to summary the results of all types of studies checking association between ACE2 and COVID-19 in a systematic review for the $1^{\text {st }}$ time. 


\section{Search strategy}

Two databases, namely, PubMed/Medline and Scopus were comprehensively searched by an author (M.S) to retrieve all relevant references published until March 18, 2020, without restrictions. The searched queries were "2019 novel coronavirus" or "2019-nCoV" or "COVID-19" or "SARS-CoV-2" and "angiotensin" or "angiotensin-converting enzyme 2" or "ACE2". We manually searched the citations (original and review articles and meta-analyses) related to our topics as well as bioRxiv (https://www.biorxiv.org/). We know that we cannot rely solely on bioRxiv preprints and papers due to the absence of peer review. However, we did not omit these articles, not to lose sources of data in a new emerging entity.

\section{Eligibility criteria}

Inclusion criteria were as follows: (1) Studies evaluating the correlation ACE2 and COVID-19 and (2) all types of studies.

\section{Study selection and data extraction}

Two authors (H.N and M.S) read independently the titles and abstracts of the retrieved studies. Then, the two authors selected the relevant studies, while another author (M.R) retrieved the full texts of the articles. Two authors (M.R and M.S) independently extracted the data from each study for being included in the systematic review. If there was a disagreement between the two authors, the third author (H.N) helped to find a final decision. The data extracted for the systematic review included basic information including the first author, publication year, type of study, and main result(s)/conclusion(s). Other authors (F.N, B.S, and M.N) rechecked independently the extracted data. At last, the disagreement resolved by a discussion between all authors.

\section{Study selection}

Out of 52 records retrieved from two databases and 10 studies from bioRxiv, after removing duplicates, 47 records were screened (Figure 1). After that, 6 other

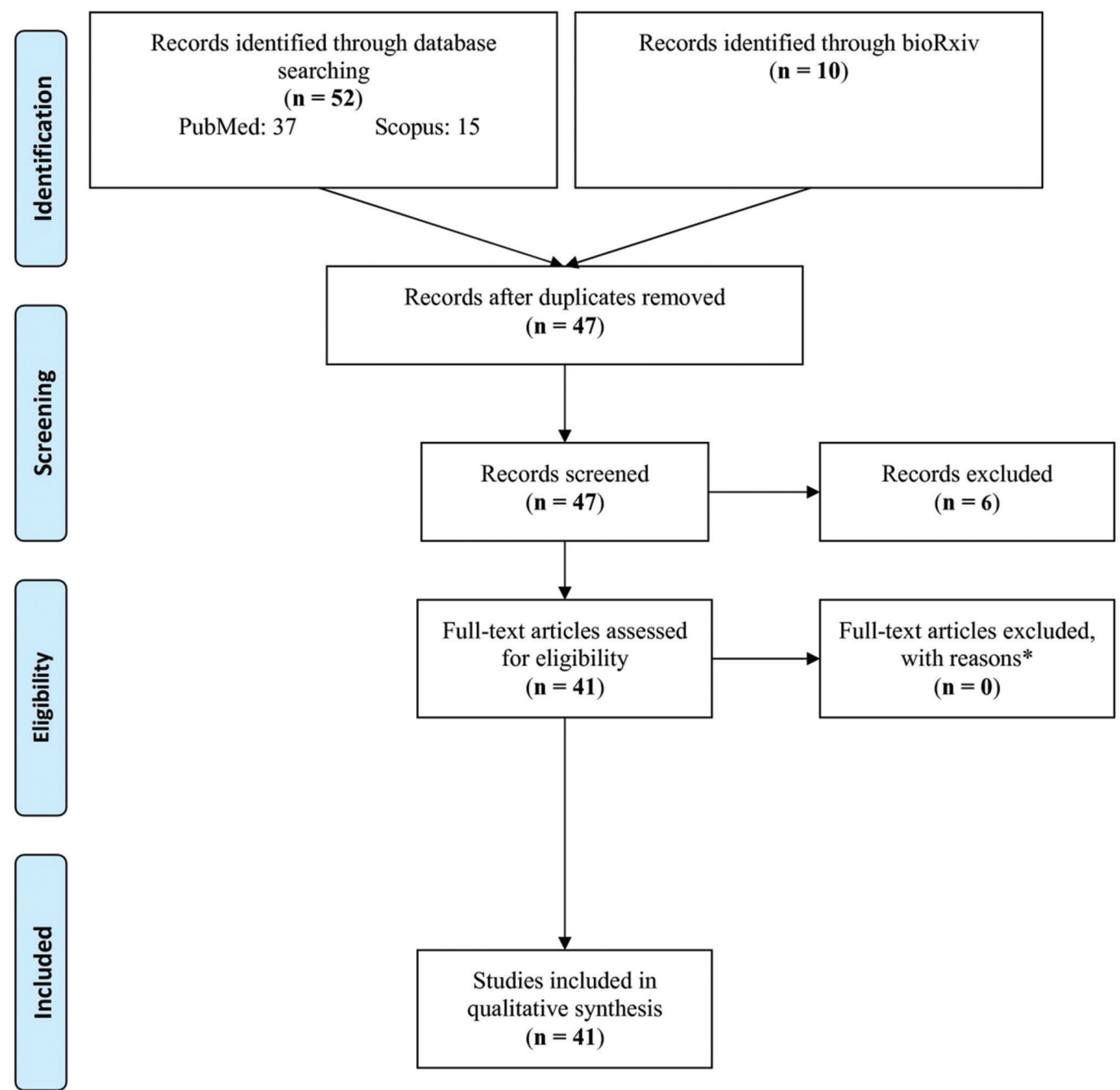

Figure 1: Flowchart of the study selection 
studies were removed with further evaluation because they were irrelevant records. At last, 41 full texts met eligibility criteria and all of them were entered to the systematic review.

\section{Characteristics}

Table 1 shows the characteristics of 41 studies included in the systematic review [4], [11], [12], [14], [15], [16], [17],[18], [19], [20], [21], [22], [23], [24], [25], [26], [27], [28], [29] [30], [31], [32], [33], [34], [35], [36], [37], [38], [39], [40], [41], [42], [43], [44], [45], [46], [47], [48], [49], [50], [51]. The studies included nineteen original articles [11], [12], [15], [17], [20], [22], [25], [28], [33], [35], [36], [40], [43], [44], [45],
[48], [49], [50], [51], eight reviews [14], [19], [23], [29], [34], [37], [38], [47], four letters to the editor [4], [18], [30], [39], three research papers [31], [32], [46], one correspondence [16], one commentary [24], one mini review [26], two reports [21], [41], one opinion [27], and one perspective [42].

\section{Blockers and inhibitors}

Host cell entry from SARS-CoV-2 is dependent on the ACE2 receptor of SARS-CoV and may be clinically prevented by a proven inhibitor of TMPRSS2, a cellular serine proteinase used by SARS-CoV-2 for $S$ protein priming. The antibody responses increased against SARS-CoV can at least partially protect

Table 1: Characteristics of studies included in systematic review

\begin{tabular}{|c|c|c|c|}
\hline First author, publication year & Type of study & Journal & Main result(s)/conclusion(s) \\
\hline Diaz, $2020[4]$ & Letter to the editor & J Travel Med & $\begin{array}{l}\text { Patients who take angiotensin-converting enzyme inhibitors and angiotensin receptor blockers may } \\
\text { be at elevated risk of severe disease outcomes because of SARS-CoV- } 2 \text {. }\end{array}$ \\
\hline Zou, 2020 [51] & Original & Front Med & Indicating the vulnerability of different organs to SARS-CoV-2. \\
\hline Guo, 2020 [23] & Review & Mil Med Res & $\begin{array}{l}\text { The ACE2 receptor of SARS-CoV is similar to SARS-CoV and mainly spreads through the } \\
\text { respiratory tract. }\end{array}$ \\
\hline Baig, 2020 [14] & Review & ACS Chem Neurosci & There was the ACE2 expression in the CNS. \\
\hline Batlle, 2020 [16] & Correspondence & Clin Sci (Lond) & $\begin{array}{l}\text { The association between SARS-CoV, SARS-CoV-2, and ACE2 suggests a rational reason for } \\
\text { soluble ACE2 as a potential treatment. }\end{array}$ \\
\hline Hoffmann, 2020 [25] & Original & Cell & SARS-CoV-2 uses the ACE2 receptor of SARS-CoV for cell entry. \\
\hline Kannan, 2020 [26] & Mini review & Eur Rev Med Pharmacol Sci & The ACE2 receptor of SARS-CoV is similar to SARS-CoV. \\
\hline Sun, 2020 [38] & Review & $\begin{array}{l}\text { Int J Environ Res Public } \\
\text { Health }\end{array}$ & SARS-CoV-2 uses the ACE2 receptor of SARS-CoV for cell entry. \\
\hline Cao, 2020 [18] & Letter to the editor & Cell Discov & High expression of ACE2 in Asian males compared to others. \\
\hline Yan, 2020 [46] & Research paper & Science & The RBD is identified by the extracellular peptidase domain of ACE2 chiefly through polar residues. \\
\hline Gurwitz, 2020 [24] & Commentary & Drug Dev Res & $\begin{array}{l}\text { Angiotensin II type I receptor (AT1R) blockers are as treatments for decreasing the aggressiveness } \\
\text { and mortality from SARS-CoV-2. }\end{array}$ \\
\hline Deng, 2020 [21] & Report & Chin Med J (Engl) & $\begin{array}{l}\text { ACE2 expression in the human kidney indicated the kidney is a potential target organ of } \\
\text { SARS-CoV-2. }\end{array}$ \\
\hline Kruse, 2020 [27] & Opinion & F1000 Research & The ACE2-Fc therapy will decrease ACE2 levels in the lungs during infection. \\
\hline Liu, 2020 [32] & Research paper & J Med Virol & SARS-CoV-2 might also use ACE2 receptor. \\
\hline Letko, 2020 [28] & Original & Nat Microbiol & The hACE2 is the receptor for the SARS-CoV- 2 . \\
\hline $\mathrm{Xu}, 2020[45]$ & Original & Int J Oral Sci & There was ACE2 expression in the mucosa of oral cavity. \\
\hline Li, 2020 [30] & Letter to the editor & J Infect & $\begin{array}{l}\text { Structural studies of human and other ACE2 species in the SARS-CoV-2 S protein complex will } \\
\text { help understand the use of cross-receptors for SARS-CoV- } 2 \text {. }\end{array}$ \\
\hline Li, 2020 [29] & Review & Microbes Infect & SARS-CoV-2 may have wide host ranges. \\
\hline Chen, $2020[20]$ & Original & $\begin{array}{l}\text { Biochem Biophys Res } \\
\text { Commun }\end{array}$ & SARS-CoV-2 RBD has a stronger interaction with ACE2. \\
\hline Guan, 2020 [22] & Original & $\begin{array}{l}\text { Zhonghua Gan Zang Bing } \\
\text { Za Zhi }\end{array}$ & $\begin{array}{l}\text { ACE2 expression was in bile duct epithelial cells of normal liver tissues, and very low in } \\
\text { hepatocytes in COVID-19 patients. }\end{array}$ \\
\hline Wrapp, 2020 [41] & Report & Science & $\begin{array}{l}\text { It has reported that the binding capacity of SARS-CoV-2 S protein to ACE2 is much stronger than } \\
\text { that of SARS-CoV, which indicts that there are more intermediate hosts for SARS-CoV- } 2 \text {. }\end{array}$ \\
\hline Tian, 2020 [39] & Letter to the editor & Emerg Microbes Infect & $\begin{array}{l}\text { CR3022 has the potential to be expanded as candidate therapeutics for the SARS-CoV-2 } \\
\text { prevention and treatment. }\end{array}$ \\
\hline Sun, 2020 [37] & Review & $\begin{array}{l}\text { Zhonghua Jie He He Hu } \\
\text { Xi Za Zhi }\end{array}$ & $\begin{array}{l}\text { The COVID-19/ACE2 binding resulted in the ACE2 exhaustion, and then, ACE2/Ang/Mas receptor } \\
\text { pathway was inhibited. }\end{array}$ \\
\hline Liu, 2020 [31] & Research paper & Sci China Life Sci & $\begin{array}{l}\text { The angiotensin II plasma level in SARS-CoV-2 patients was significantly increased and linearly } \\
\text { associated to viral load and lung injury. }\end{array}$ \\
\hline Wu, $2020[42]$ & Perspective & Virol Sin & SARS-CoV-2 uses the same cell entry ACE2 receptor similar to SARS-CoV. \\
\hline Chen, 2020 [19] & Review & Microbes Infect & CoV-NL63 uses the same receptor ACE2 as SARS-CoV-2, but with very different severity of disease. \\
\hline Morse, $2020[34]$ & Review & Chembiochem & $\begin{array}{l}\text { Potential drug candidates (an ACE2-based peptide, remdesivir, CLpro-1, and a novel vinylsulfone } \\
\text { protease inhibitor) could be used to treat COVID-19 patients. }\end{array}$ \\
\hline Zhou, 2020 [50] & Original & Nature & SARS-CoV-2 uses the same cell entry receptor - ACE2 - as SARS-CoV. \\
\hline Walls, 2020 [40] & Original & Cell & $\begin{array}{l}\text { The receptor-binding domains of SARS-CoV-2 S and SARS-CoV S bind with similar affinities to } \\
\text { human ACE2. }\end{array}$ \\
\hline Zhang, 2020 [47] & Review & Intensive Care Med & ACE2 is rationally and scientifically valid therapeutic target for the current COVID-19 epidemic. \\
\hline Lu, 2020 [12] & Original & Lancet & SARS-CoV-2 might be able to bind to the ACE2 receptor in humans. \\
\hline $\mathrm{Wu}, 2020[43]$ & Original & bioRxiv & $\begin{array}{l}\text { Bat SARS-like CoVs have an evolutionary convergent RBD sequence with SARS-CoV-2 and } \\
\text { SARS-CoV may be pre-adapted to hACE2 receptor. }\end{array}$ \\
\hline Brielle, 2020 [17] & Original & bioRxiv & $\begin{array}{l}\text { Evolution of S protein binding to the ACE } 2 \text { receptor is similar to the rapid evolution along the } \\
\text { antibody-antigen affinity maturation process. }\end{array}$ \\
\hline Lukassen, 2020 [33] & Original & bioRxiv & $\begin{array}{l}\text { The high rate of human-to-human transmission of SARS-CoV-2 and severe cases of COVID-19 may } \\
\text { be caused by additional sites, resulting in a higher binding affinity of ACE2 and/or membrane fusion. }\end{array}$ \\
\hline Othman, 2020 [35] & Original & bioRxiv & $\begin{array}{l}\text { The S protein RBD might be obtained by SARS-CoV- } 2 \text { through a complex evolutionary process } \\
\text { rather than the accumulation of mutations. }\end{array}$ \\
\hline Su, $2020[36]$ & Original & bioRxiv & The SARS-CoV-2 S protein mediates its recognition with the human receptor ACE2. \\
\hline Bao, 2020 [15] & Original & bioRxiv & The mouse model may simplify the therapeutic and vaccine development against SARS-CoV- 2 . \\
\hline Zhang, 2020 [48] & Original & bioRxiv & Pangolin-CoV will be useful for tracing the origin and potential host of SARS-CoV-2. \\
\hline Xie, 2020 [44] & Original & bioRxiv & $\begin{array}{l}\text { SARS-CoV-2 and SARS-CoV bind to hACE2 with same affinities and consequently may have same } \\
\text { transmissibility. }\end{array}$ \\
\hline Meng, 2020 [11] & Original & bioRxiv & $\begin{array}{l}\text { The single-cell RNA sequencing showed that high expression of ACE2 in type II alveolar cells (AT2) } \\
\text { cells of lung, esophageal upper epithelial cells, and absorptive enterocytes. }\end{array}$ \\
\hline Zhao, 2020 [49] & Original & bioRxiv & ACE2 receptor is necessary for the SARS-CoV-2 viral entry. \\
\hline
\end{tabular}


against SARS-CoV-2 [25]. Patients under treatment with angiotensin-converting enzyme inhibitors (ACEIs) and angiotensin receptor blockers (ARBs) increase the number of ACE2 receptors in their lungs to bind to coronavirus $\mathrm{S}$ proteins, thus may be at elevated risk for severe disease outcomes due to SARS-CoV-2 virus. Many patients with cardiovascular disease are treated with ACEIs and ARBs, so their ACE2 receptors are increased. In fact, the patients for cardiovascular diseases should refrain from congestion, mass accidents, ocean cruises, prolonged air travel, and all cases with respiratory illnesses during COVID-19 outbreaks to reduce the risks of infection of SARS-CoV-2 virus [4]. ACE2 is likely to act as the SARS-CoV-2 virus junction [24], [25] and the strain involved in the current COVID-19 epidemic is similar to the SARS-CoV strain in the 2002-2003 SARS epidemic [24]. However paradoxically, AT1R blockers, such as losartan, can be as tentative treatment to decrease the aggressive forms and mortality caused by SARS-CoV-2 virus. Higher expression of ACE2 with losartan protects against lung injury by complementary mechanisms: (1) Blocking the excessive angiotensin-mediated AT1R activation caused by viral infection and (2) upregulating ACE2 culminating in reducing angiotensin production by ACE and increasing angiotensin 1-7 (vasodilator) [24]. Broking the balance of the RAS (renin-angiotensin system) leads to aggravation of severe acute pneumonia. However, it is speculated that ACEI and AT1R inhibitors can be used in COVID-19 pneumonia patients under controlling hypertension and may decrease the pulmonary inflammatory response and mortality [37]. Further research is needed for approving this treatment modality in COVID and side effect of hypotension must be kept in mind [24].

\section{Cell expression}

Among 536 COVID-19 patients, 6.7\% presented acute kidney injury (AKI) in spite of normal plasma levels of creatinine at the first clinical manifestation, and these patients experienced exceedingly great mortality of up to $91.7 \%$ [52]. A report showed ACE2 expression in the human kidney and that the kidney is a possible target organ of SARS-CoV-2 virus [21]. ACE2 expression was established in several other human organs such as the intestines (glandular cells), gallbladder (glandular cells), adrenal gland, lungs, and lung macrophages and the expression was highly in the urogenital, digestive systems, and the proximal tubules. In addition, the single-cell RNA sequencing (scRNA-seq) showed that ACE2 is highly coexpressed in type II alveolar cells of lung, along with esophageal upper epithelial cells and absorptive enterocytes [11]. These results may propose that antibodies or biological inhibitors may target virus proteins such as $S$ protein showing that the ACE2 receptor can be a part of therapeutic guidelines of SARS-CoV-2 virus [21]. Interestingly, this receptor is highly enriched in tongue epithelial cells, and the findings have explained the underlying mechanism that the oral cavity is another potential risk for the SARS-CoV-2 virus [45]. The scRNA-seq data of fetal and adult kidney samples appeared that ACE2 expression was significantly in tubule cells [21] and also in myocardial cells $(>7.5 \%)$, ileal epithelial cells $(\sim 30 \%)$, esophagus epithelial cells $(>1 \%)$, kidney proximal tubule $(<1 \%)$, and bladder urothelial cells $(2.4 \%)$ [51]. Therefore, the pattern of ACE2 expression shows other modes of SARS-CoV transmission that may involve the intestine, testis, kidney, and other tissue functions [19]

One study reported the ACE2 expression in neurological tissue that this illustrates a connection between the tissue damage and the morbidity and mortality by SARS-CoV-2 [14]. A mouse model checking acute liver injury with partial hepatectomy showed that ACE2 expression changed after treatment (day 1: Downregulated, day 3: Increased up to twice of the normal level, and day 7 or liver recovering: Returned to the normal level). Based on scRNA-seq data, 77 transcription factors were positively related to the ACE2 expression, which were mainly enriched in the development, differentiation, morphogenesis, and cell proliferation of glandular epithelial cells. This ACE2 expression upregulation in liver tissue induced by compensatory hepatocyte proliferation obtained from bile duct epithelial cells may also be the possible mechanism of liver tissue injury caused by COVID-19 [32]. The ACE2 expression in several cells, such as to lung type II alveolar cells, upper part of esophagus, epithelial cells, and ileum- and colon-absorbing enterocytes, may play to a role of the multitissue infection of SARS-CoV-2 [49]. Around $40 \%$ of ACE2-positive transient secretory cells are coexpressing TMPRSS2 proteinase, including FURIN as another proteinase in SARS-CoV-2 entry of the host cell, the percentage of transient secretory cells expressing the ACE2 receptor, both or one of the TMPRSS2 and FURIN proteinases increased by up to $50 \%$. Thus, these cells can be highly vulnerable to SARS-CoV-2 infection [33].

\section{proteins}

\section{Receptor-binding domain (RBD) and}

Human ACE2 (hACE2) is a receptor for different lineage $B$ viruses such as SARS-CoV-2 to gain entry into human cells [28]. The CoV S glycoprotein plays a significant target for therapeutic antibodies, vaccines, and diagnostics [41] that affinity of SARS-CoV-2 S protein bind to ACE2 is more than SARS-CoV $S$ protein. Antibody cross-reactivity is limited between the two RBDs [40]. Glycosylation may impact on interaction of the RBD with ACE2, and therefore, the aim is to test the drugs for their ability to block the RBD/ACE2 interaction. Antibodies and small molecular inhibitors blocking the RBD/ACE2 interaction should be developed to combat the SARS-CoV-2 virus [19]. Checking m396 and CR3014 (SARS-CoV-specific neutralizing antibodies) 
that target the ACE2 binding site of SARS-CoV, there was no bind to SARS-CoV-2 S protein [38]. RdRp and 3CLpro regions of RBD binding to ACE2 are significantly different between the SARS-CoV and SARS-CoV-2 [11], [34]. This difference effectively rules out the use of previously developed antibodies and therapeutic peptides for the SARS-CoV S RBD [11]. Therefore, the difference in the RBD of between two viruses (SARS-CoV and SARS-CoV-2) shows a critical impact for the antibodies and that it should develop novel monoclonal antibodies that could bind specifically to SARS-CoV-2 RBD. To prevent SARS-CoV-2 and COVID-19 treatment, CR3022 does not overlap with the ACE2 binding site of SARS-CoV-2 RBD, and therefore, CR3022 may be as a candidate treatment, alone or in connection to other neutralizing antibodies [38]. One perspective study [32] checked Asn501 in RBD with the sites 41 and 353 of ACE2 receptor and the result showed that turtles and pangolins as potential expanded hosts of SARS-CoV-2 are closer to humans than bat [32]. Furthermore, the Q493 and P499 amino acid residues of SARS-CoV-2 RBD bind to hACE2 and maintain interface stability, neither of which is likely to interact with SARS-CoV-2 RBD [34]. SARS-CoV-2 and SARS-CoV interfaces include long flexible loops and nine aromatic residues in the interface with ACE2 [16].

Bat SARS-like CoVs have a RBD sequence with high similarity to SARS-CoV-2 [43]. ACE2 is widely expressed with conserved primary structures throughout the animal kingdom from fish, amphibians, reptiles, birds, to mammals. Therefore, it suggests that ACE2 from these animals (possible natural hosts for the virus) can potentially bind SARS-CoV-2 RBD [20]. Antibodies targeting the receptor-binding motif (RBM) regions may have more potential because of their ACE2 blocking activities but cross-protecting antibodies [43]. Another study [48] checking interactions of hACE2 between pangolin-CoV and SARS-CoV-2 showed that the S1 protein of pangolin-CoV was very closely related to SARS-CoV-2 than RaTG13 and this result shows a similar pathogenic potential of pangolinCoV to SARS-CoV-2, showing pangolin as probable intermediate host of SARS-CoV-2 [29]. The nucleocapsid (N) protein of SARS-CoV-2 has approximately $90 \%$ amino acid sequence similar to SARS-CoV that therefore the $\mathrm{N}$ protein antibodies of SARS-CoV may cross-react with SARS-CoV-2 but may not provide cross-immunity. The $\mathrm{N}$ protein of SARS-CoV-2 may have a significant role in suppressing the RNA interference (RNAi) to overcome the host defense, similar to SARS-CoV [25]. One study [39] reported the striking structural similarity and sequence conservation among the SARS-CoV-2 S and SARS-CoV S glycoproteins emphasize the close correlation between these two viruses that recognize hACE2 to enter target cells [45]. The interaction between the key amino acids of $S$ protein RBD and ACE2 indicated that except for pangolins and snakes, turtles may be as other potential intermediate hosts transmitting SARS-CoV-2 to humans [31].

\section{Mutation}

ACE2 sequence and structure from different species alert to potential intermediate translocation of SARS-CoV-2 and provide further monitoring in other animals [30]. Genotype distribution and allele frequencies (AFs) may be involved in further ACE2 research, including its role in lung function and acute lung injury. The AFs in the Eastern Asian people were much higher and associated with higher ACE2 expression in tissues that may propose different susceptibility or response to SARS-CoV-2 among different populations under the same conditions [17]. The distribution of ACE2-expressing cell population in different cohorts showed potentially identifies the susceptible population: Asian donor (male): $2.50 \%$ of all cells and African-American donors: $0.47 \%$ of all cells [49]. Furthermore, the ACE2 distribution is also more prevalent in male donors than females [49].

\section{Treatment}

The less correlation between SARS-CoV-2 and ACE2 can lead to longer incubation time, while still having a relatively higher level of viral concentration in human body [36]. CoV-NL63 uses the same ACE2 receptor as SARS-CoV-2, whereas it creates very different severity of disease [19]. Several studies [16], [23], [26], [38], [42], [50] demonstrate that SARS-CoV-2 uses the SARS-CoV receptor ACE2 for entry and to explain the connection between the SARS-CoV, SARS-CoV-2, ACE2, and the rationale for soluble ACE2 as a potential therapy [16]. Furthermore, checking the sites of interaction between ACE2 and SARS-CoV at the atomic level showed the interaction between ACE2 and SARS-CoV-2 [46]. The ACE2-immunoglobulin Fc domain (ACE2-Fc) protein sequence was investigated and the result showed that the ACE2-Fc therapy would also supplement reduced ACE2 levels in the lungs during infection, thereby directly treating acute respiratory distress pathophysiology as a third mechanism of action before a protective vaccine is administrated and widely available in the coming months to year(s) in the COVID-19 patients [27]. Results have shown that angiotensin II levels in plasma samples from 2019-nCoV-infected patients are significantly correlated linearly with viral load and lung injury, suggesting a number of diagnostic potential biomarkers and ARB drugs for the treatment of 2019-nCoV [31]. Weight loss and virus replication in the lungs were noticed in hACE2 mice infected with SARS-CoV-2 and this event was not established in wild-type mice with SARS-CoV-2. Therefore, the mouse model may make easier the treatment and vaccine development against SARS-CoV-2 [15].

\section{Limitations}

COVID-19 is a new emerging disease so the researches for systematic review are limited. Some studies may have lower levels of validity with fast peer 
review. More time is needed for evaluating the results of clinical trials.

\section{Conclusion}

Whatever there were some different residues for ACE2 receptor between SARS-CoV-2 and SARSCoV, but most studies showed that the ACE2 receptor for SARS-CoV-2 is similar to that of SARS-CoV, and therefore, ACE2 is rationally and scientifically valid therapeutic target for the current COVID-19 pandemic. Therefore, four potential drug candidates (an ACE2-based peptide, remdesivir, CLpro-1, and a novel vinylsulfone protease inhibitor) may use to treat COVID-19 patients. ACE2 expression was found in several human organs introducing new organs such as brain tissue and oral cavity and the expression in various populations was different as well as in the two genders. These data may be used for epidemiologic, diagnostic, and therapeutic purposes. Patients who take ACEls and ARBs may have benefit in severe disease outcomes due to SARS-CoV-2, but further investigation is necessary. The RBD/ACE2 interaction suggested pangolins and snakes, and turtles may act as the potential intermediate hosts transmitting SARSCoV-2 to humans.

\section{Acknowledgments}

This study was approved by the Ethics Committee of Kermanshah University of Medical Sciences, Kermanshah, Iran (Code: IR.KUMS. REC.1399.045).

\section{References}

1. World Health Organization. Coronavirus Disease (COVID-19) Outbreak. Available from: https://www.who.int/emergencies/ diseases/novel-coronavirus-2019. [Last accessed on 2020 Mar 05].

2. Cheng ZJ, Shan J. 2019 novel coronavirus: Where we are and what we know. Infection. 2020;48(2):155-63. https://doi. org/10.1007/s15010-020-01401-y

PMid:32072569

3. Zhou P, Yang XL, Wang XG, Hu B, Zhang L, Zhang W, et al. Discovery of a novel coronavirus associated with the recent pneumonia outbreak in humans and its potential bat origin. BioRxiv. 2020;2020:914952. https://doi. org/10.1101/2020.01.22.914952

4. Diaz JH. Hypothesis: Angiotensin-converting enzyme inhibitors and angiotensin receptor blockers may increase the risk of severe COVID-19. J Travel Med. 2020;27(3):taaa041. https:// doi.org/10.1093/jtm/taaa041

PMid:32186711

5. Crackower MA, Sarao R, Oudit GY, Yagil C, Kozieradzki I, Scanga SE, et al. Angiotensin-converting enzyme 2 is an essential regulator of heart function. Nature. 2002;417(6891):822-8. https://doi.org/10.1038/nature00786 PMid:12075344

6. Hulswit R, de Haan C, Bosch BJ. Coronavirus spike protein and tropism changes. Adv Virus Res. 2016;96:29-57. https://doi. org/10.1016/bs.aivir.2016.08.004

PMid:27712627

7. Li F. Structure, function, and evolution of coronavirus spike proteins. Annu Rev Virol. 2016;3(1):237-61. https://doi. org/10.1146/annurev-virology-110615-042301

PMid:27578435

8. Belouzard S, Millet JK, Licitra BN, Whittaker GR. Mechanisms of coronavirus cell entry mediated by the viral spike protein. Viruses. 2012;4(6):1011-33. https://doi.org/10.3390/v4061011 PMid:22816037

9. Gallagher TM, Buchmeier MJ. Coronavirus spike proteins in viral entry and pathogenesis. Virology. 2001;279(2):371-4. https://doi.org/10.1006/viro.2000.0757 PMid:11162792

10. Li F, Li W, Farzan M, Harrison SC. Structure of SARS coronavirus spike receptor-binding domain complexed with receptor. Science. 2005;309(5742):1864-8. https://doi.org/10.1126/ science. 1116480

PMid:16166518

11. Meng $\mathrm{T}$, Cao $\mathrm{H}$, Zhang $\mathrm{H}$, Kang $\mathrm{Z}, \mathrm{Xu} \mathrm{D}$, Gong $\mathrm{H}$, et al. The insert sequence in SARS-CoV-2 enhances spike protein cleavage by TMPRSS. BioRxiv. 2020;2020:926006. https://doi. org/10.1101/2020.02.08.926006

12. Lu R, Zhao X, Li J, Niu P, Yang B, Wu H, et al. Genomic characterisation and epidemiology of 2019 novel coronavirus: Implications for virus origins and receptor binding. Lancet. 2020;395(10224):565-74.

PMid:32007145

13. Udugama B, Kadhiresan $P$, Kozlowski HN, Malekjahani $A$, Osborne M, Li V, et al. Diagnosing COVID-19: The disease and tools for detection. ACS Nano. 2020;14(4):0c02624. https://doi. org/10.1021/acsnano.0c02624

PMid:32223179

14. Baig AM, Khaleeq A, Ali U, Syeda H. Evidence of the COVID19 virus targeting the CNS: Tissue distribution, host-virus interaction, and proposed neurotropic mechanisms. ACS Chem Neurosci. 2020;11(7):995-8. https://doi.org/10.1021/ acschemneuro.0c00122 PMid:32167747

15. Bao L, Deng W, Huang B, Gao H, Liu J, Ren L, et al. The pathogenicity of SARS-CoV-2 in hACE2 transgenic mice. BioRxiv. 2020;2020:939389. https://doi.org/10.1101/2020.02.07.939389

16. Batlle D, Wysocki J, Satchell K. Soluble angiotensin-converting enzyme 2: A potential approach for coronavirus infection therapy? Clin Sci (Lond). 2020;134(5):543-5. https://doi. org/10.1042/cs20200163

PMid:32167153

17. Brielle ES, Schneidman D, Linial M. The SARS-CoV-2 exerts a distinctive strategy for interacting with the ACE2 human receptor. BioRxiv. 2020;2020:986398. https://doi. org/10.1101/2020.03.10.986398

18. Cao Y, Li L, Feng Z, Wan S, Huang P, Sun X, et al. Comparative genetic analysis of the novel coronavirus (2019-nCoV/ 
SARS-CoV-2) receptor ACE2 in different populations. Cell Discov. 2020;6:11. https://doi.org/10.1038/s41421-020-0147-1 PMid:32133153

19. Chen J. Pathogenicity and transmissibility of 2019-nCoV-A quick overview and comparison with other emerging viruses. Microbes Infect. 2020;22(2):69-71. https://doi.org/10.1016/j. micinf.2020.01.004

PMid:32032682

20. Chen Y, Guo Y, Pan Y, Zhao ZJ. Structure analysis of the receptor binding of 2019-nCoV. Biochem Biophys Res Commun. 2020;525(1):135-40

PMid:32081428

21. Deng YY, Zheng Y, Cai GY, Chen XM, Hong Q. Single-cell RNA sequencing data suggest a role for angiotensin-converting enzyme 2 in kidney impairment in patients infected with 2019nCoV. Chin Med J (Engl). 2020;133(9):1129-31. https://doi. org $/ 10.1097 / \mathrm{cm} 9.0000000000000783$

PMid:32118645

22. Guan GW, Gao L, Wang JW, Wen XJ, Mao TH, Peng SW, et al. Exploring the mechanism of liver enzyme abnormalities in patients with novel coronavirus-infected pneumonia. Zhonghua Gan Zang Bing Za Zhi. 2020;28(2):E002. PMid:32077659

23. Guo YR, Cao QD, Hong ZS, Tan YY, Chen SD, Jin HJ, et al. The origin, transmission and clinical therapies on coronavirus disease 2019 (COVID-19) outbreak-an update on the status. Mil Med Res. 2020;7(1):11. https://doi.org/10.1186/s40779-020-00240-0 PMid:32169119

24. Gurwitz D. Angiotensin receptor blockers as tentative SARSCoV-2 therapeutics. Drug Dev Res. 2020;2020:21656. https:// doi.org/10.1002/ddr.21656 PMid:32129518

25. Hoffmann M, Kleine-Weber H, Schroeder S, Kruger N, Herrler T, Erichsen S, et al. SARS-CoV-2 cell entry depends on ACE2 and TMPRSS2 and is blocked by a clinically proven protease inhibitor. Cell. 2020;181(2):271-80.e8. https://doi.org/10.1016/j. cell.2020.02.052

PMid:32142651

26. Kannan S, Ali PS, Sheeza A, Hemalatha K. COVID-19 (novel coronavirus 2019)-recent trends. Eur Rev Med Pharmacol Sci. 2020;24(4):2006-11.

PMid:32141569

27. Kruse RL. Therapeutic strategies in an outbreak scenario to treat the novel coronavirus originating in Wuhan, China. F1000Res. 2020;9:72. https://doi.org/10.12688/f1000research.22211.2 PMid:32117569

28. Letko M, Marzi A, Munster V. Functional assessment of cell entry and receptor usage for SARS-CoV-2 and other lineage $B$ betacoronaviruses. Nat Microbiol. 2020;5(4):562-9. https://doi. org/10.1038/s41564-020-0688-y PMid:32094589

29. Li JY, You Z, Wang Q, Zhou ZJ, Qiu Y, Luo R, et al. The epidemic of 2019-novel-coronavirus (2019-nCoV) pneumonia and insights for emerging infectious diseases in the future. Microbes Infect. 2020;22(2):80-5. https://doi.org/10.1016/j. micinf.2020.02.002

PMid:32087334

30. Li R, Qiao S, Zhang G. Analysis of angiotensin-converting enzyme 2 (ACE2) from different species sheds some light on cross-species receptor usage of a novel coronavirus 2019nCoV. J Infect. 2020;80(4):469-6. https://doi.org/10.1016/j. jinf.2020.02.013 PMid:32092392

31. Liu $Y$, Yang $Y$, Zhang $C$, Huang $F$, Wang $F$, Yuan J, et al.
Clinical and biochemical indexes from 2019-nCoV infected patients linked to viral loads and lung injury. Sci China Life Sci. 2020;63(3):364-74. https://doi.org/10.1007/s11427-020-1643-8 PMid:32048163

32. Liu Z, Xiao X, Wei X, Li J, Yang J, Tan H, et al. Composition and divergence of coronavirus spike proteins and host ACE2 receptors predict potential intermediate hosts of SARSCoV-2. J Med Virol. 2020;2020:25726. https://doi.org/10.1002/ jmv. 25726

PMid:32100877

33. Lukassen S, Chua RL, Trefzer T, Kahn NC, Schneider MA, Muley $\mathrm{T}$, et al. SARS-CoV-2 receptor ACE2 and TMPRSS2 are predominantly expressed in a transient secretory cell type in subsegmental bronchial branches. BioRxiv. 2020;2020:991455. https://doi.org/10.1101/2020.03.13.991455

34. Morse JS, Lalonde T, Xu S, Liu WR. Learning from the past: Possible urgent prevention and treatment options for severe acute respiratory infections caused by 2019-nCoV. Chembiochem. 2020;21(5):730-8. https://doi.org/10.1002/ cbic. 202000047

PMid:32022370

35. Othman H, Bouslama Z, Brandenburg JT, Da Rocha J, Hamdi Y, Ghedira K, et al. In silico study of the spike protein from SARSCoV-2 interaction with ACE2: Similarity with SARS-CoV, hotspot analysis and effect of the receptor polymorphism. BioRxiv. 2020;2020:028. https://doi.org/10.1016/j.bbrc.2020.05.028

36. Su Z, Wu Y. A multiscale and comparative model for receptor binding of 2019 novel coronavirus and the implication of its life cycle in host cells. BioRxiv. 2020;2020:958272. https://doi. org/10.1101/2020.02.20.958272

37. Sun ML, Yang JM, Sun YP, Su GH. Inhibitors of RAS might be a good choice for the therapy of COVID-19 pneumonia. Zhonghua Jie He He Hu Xi Za Zhi. 2020;43(3):E014.

PMid:32061198

38. Sun Z, Thilakavathy K, Kumar SS, He G, Liu SV. Potential factors influencing repeated SARS outbreaks in China. Int J Environ Res Public Health. 2020;17(5):E1633. https://doi. org/10.3390/ijerph17051633 PMid:32138266

39. Tian X, Li C, Huang A, Xia S, Lu S, Shi Z, et al. Potent binding of 2019 novel coronavirus spike protein by a SARS coronavirusspecific human monoclonal antibody. Emerg Microbes Infect. 2020;9(1):382-5. https://doi.org/10.1101/2020.01.28.923011 PMid:32065055

40. Walls AC, Park YJ, Tortorici MA, Wall A, McGuire AT, Veesler D. Structure, function, and antigenicity of the SARS-CoV-2 spike glycoprotein. Cell. 2020;181(2):281-92.e6. https://doi. org/10.1016/j.cell.2020.02.058

PMid:32155444

41. Wrapp D, Wang N, Corbett KS, Goldsmith JA, Hsieh CL, Abiona O, et al. Cryo-EM structure of the 2019-nCoV spike in the prefusion conformation. Science. 2020;367(6483):1260-3. https://doi.org/10.1126/science.abb2507 PMid:32075877

42. Wu Y. Compensation of ACE2 function for possible clinical management of 2019-nCoV-induced acute lung injury. Virol Sin. 2020;1:1-3. https://doi.org/10.1007/s12250-020-00205-6 PMid:32034638

43. Wu Y. Strong evolutionary convergence of receptor-binding protein spike between COVID-19 and SARS-related coronaviruses. BioRxiv. 2020;2020:975995. https://doi. org/10.1101/2020.03.04.975995

44. Xie L, Sun C, Luo C, Zhang Y, Zhang J, Yang J, et al. SARSCoV-2 and SARS-CoV spike-RBD structure and receptor binding comparison and potential implications on neutralizing antibody 
and vaccine development. BioRxiv. 2020;2020:951723. https:// doi.org/10.1101/2020.02.16.951723

45. Xu H, Zhong L, Deng J, Peng J, Dan H, Zeng X, et al. High expression of ACE2 receptor of 2019-nCoV on the epithelial cells of oral mucosa. Int J Oral Sci. 2020;12(1):8. https://doi. org/10.1038/s41368-020-0074-x

PMid:32094336

46. Yan R, Zhang Y, Li Y, Xia L, Guo Y, Zhou Q. Structural basis for the recognition of the SARS-CoV-2 by full-length human ACE2. Science. 2020;367(6485):1444-8. https://doi.org/10.1126/ science.abb2762

PMid:32132184

47. Zhang H, Penninger JM, Li Y, Zhong N, Slutsky AS. Angiotensinconverting enzyme 2 (ACE2) as a SARS-CoV-2 receptor: Molecular mechanisms and potential therapeutic target. Intensive Care Med. 2020;46(4):586-90. https://doi.org/10.1007/ s00134-020-05985-9 PMid:32125455

48. Zhang $Z$, Wu Q, Zhang T. Pangolin homology associated with 2019-nCoV. BioRxiv. 2020;2020:950253. https://doi. org/10.1101/2020.02.19.950253

49. Zhao $Y$, Zhao Z, Wang $Y$, Zhou $Y$, Ma Y, Zuo W. Single-cell RNA expression profiling of ACE2, the putative receptor of Wuhan 2019-nCov. BioRxiv. 2020;2020:919985. https://doi. org/10.1101/2020.01.26.919985

50. Zhou P, Yang XL, Wang XG, Hu B, Zhang L, Zhang W, et al. A pneumonia outbreak associated with a new coronavirus of probable bat origin. Nature. 2020;579(7798):270-3. PMid:32015507

51. Zou X, Chen K, Zou J, Han P, Hao J, Han Z. Single-cell RNAseq data analysis on the receptor ACE2 expression reveals the potential risk of different human organs vulnerable to 2019nCoV infection. Front Med. 2020;14(2):185-92. https://doi. org/10.1007/s11684-020-0754-0

PMid:32170560

52. Chu KH, Tsang WK, Tang CS, Lam MF, Lai FM, To KF, et al. Acute renal impairment in coronavirus-associated severe acute respiratory syndrome. Kidney Int. 2005;67(2):698-705. https:// doi.org/10.1111/j.1523-1755.2005.67130.x

PMid: 15673319 